\title{
EFFECT OF HIGH DOSE OF BUTYLPARABEN ON LIVER WEIGHT OF OVARIECTOMISED C3H ALBINO MICE
}

\author{
Pallabi Goswami ${ }^{*}$, J.C Kalita ${ }^{2}$ \\ ${ }^{1}$ Research Scholar, Animal Physiology \& Biochemistry Laboratory, Department Of Zoology, Gauhati University, \\ Assam, India \\ ${ }^{2}$ Professor, Animal Physiology \& Biochemistry Laboratory, Department Of Zoology, Gauhati University, Assam, India
}

Received on: 02/10/12 Revised on: 30/11/12 Accepted on: 10/12/12

\author{
*Corresponding author \\ E-mail: goswami.pallabi29@gmail.com \\ DOI: 10.7897/2277-4343.04132 \\ Published by Moksha Publishing House. Website www.mokshaph.com \\ All rights reserved.
}

\section{ABSTRACT}

Exposure to natural and synthetic chemicals in the environment, with potential to interfere with the endocrine system, may elicit a wide range of toxic effects in wild-life and in humans, in particular on the reproductive system and with respect to the induction of cancer. Natural estrogens are a group of compounds that are steroid in nature and are primary female sex hormones. Butylparaben, a widely used preservative in many pharmaceuticals, personal care products and foodstuff is found to be estrogenic in nature and elicit toxic effect in various organs including liver, thyroid, kidney, spleen and reproductive organs. For the experiment two doses of butylparaben of $500 \mathrm{mg} / \mathrm{kg}$ body weight/day and $1000 \mathrm{mg} / \mathrm{Kg}$ body weight/day was considered. The ovariectomised $\mathrm{C} 3 \mathrm{H}$ albino mice were grouped as vehicle control (olive oil), positive control (estradiol) and the above two doses of butylparaben which were administered for seven consecutive days through subcutaneous route of administration. After the short-term exposure of seven consecutive days, butylparaben was found to increase in liver weight of ovariectomised C3H albino mice. Positive control (estradiol) showed a significant increase in liver weight $(\mathrm{p}<0.01$ ) compared to as vehicle control (olive oil). $500 \mathrm{mg} / \mathrm{kg}$ body weight $/ \mathrm{day}$ and $1000 \mathrm{mg} / \mathrm{kg}$ body weight $/ \mathrm{day}$ group showed a significant increase in liver weight $(\mathrm{p}<0.01)$ as compared to vehicle control (olive oil).

Keywords: Butylparaben, Estradiol, Liver weight, Preservative

\section{INTRODUCTION}

Natural estrogens are a group of compounds that are steroid in nature and are primary female sex hormones. The three major naturally occurring estrogens in women are estrone (E1), estradiol (E2), and estriol (E3). Although estrogen exists in men as well as women, it is found in higher amounts in women, especially those capable of reproducing. Estrogen contributes to the development of secondary sex characteristics, which are the defining differences between men and women which do not relate to the reproductive system. Environmental estrogens are natural or synthetic chemicals that mimic, enhance or inhibit endogenous hormones ${ }^{1,4}$. These are also called as Xenoestrogens, and are false estrogens found in chemicals that bind with estrogen receptor sites in the human body, causing cellular functions to change ${ }^{1,3,5}$. Exposure to these substances occurs through food, air, water, soil, household products and probably through breast milk and during development in mother's womb ${ }^{4}, 6$. The human health risks that may be associated with the constant exposures of these compounds which is still largely unknown and highly controversial ${ }^{1,8}$.

Butylparaben is a widely used preservative in many pharmaceuticals and personal care products for its efficiency in preventing microbial growth in the products where it is added ${ }^{2}, 5$. However in recent years there has been increasing concern over the wide use of butylparaben as it is found to exhibit estrogenic activity in many experimental systems including both in vivo and in vitro system along with reproductive toxicity and elicit toxic effect in various organs including liver, thyroid, kidney and spleen ${ }^{2}, 7,8$. Butylparaben is found to be 10,000 fold times less potent than $17 \beta$ estradiol $^{9}$.

\section{MATERIALS AND METHODS}

Animals and Housing

For the experiment female albino mice of $\mathrm{C} 3 \mathrm{H}$ strain were selected from animal house facility of Department of zoology, Gauhati University. (The ethical clearance number of animal study of Gauhati University was 902/AC/05/CPCSEA). The animals were housed in wire mesh plastic cages with solid bottom containing saw dust and maintained under uniform condition of natural photoperiod (12 hr light/dark cycle), relative humidity $(75 \%-87 \%)$ and temperature $\left(30 \pm 2^{\circ} \mathrm{C}\right)$. The mice had free access to water and commercially available animal diet, vitamins and mineral supplement (purchased from Agrivet Farm Care Division, Glaxo Smithkline, Chennai, India) and were fed ad libitum.

Estrous cycle was observed everyday by microscopic examination of vaginal smear. Only mice showing four consecutive cycles were consider for the experiment.

Preparation of doses of butylparaben

Butylparaben (Sigma Aldrich) was prepared in doses of $500 \mathrm{mg} / \mathrm{kg}$ body weight/day and $1000 \mathrm{mg} / \mathrm{kg}$ body weight/day. Due to solubility constraint, butylparaben was first dissolved in ethanol and then in olive oil.

\section{Preparation of $17 \beta$ estradiol}

Due to solubility constraint, 500ng of estradiol was prepared by dissolving estradiol first in ethanol then in olive oil.

\section{Experiment design}

The mice were subjected to complete bilateral ovariectomy following the method used by Kalita et al., (1998). Ovariectomy leads to removal of the major source of estrogen hormone in the blood and thus the estrogen sensitive tissue in the body remains in there basal state. 
After bilateral ovariectomy the mice are allowed to recover for 12 days.

\section{Administration of dose}

Female mice of 8 weeks of age group and of average body weight $25 \pm 2 \mathrm{~g}$ were selected for the experiment. The ovariectomised mice were grouped into four groups $(n=6)$ and were administered with $20 \mu$ live oil (vehicle control group), 500ng estradiol (positive control group) and two doses of butylparaben of $500 \mathrm{mg} / \mathrm{kg}$ body weight/day and $1000 \mathrm{mg} / \mathrm{kg}$ body weight/day.

After $24 \mathrm{hrs}$ of last dose the mice were weighed and sacrificed by cervical dislocation under mild anaesthesia (di ethylether) and liver was collected, cleared of fats and vascular tissue, if any and weighed.

Table 1: Effect of Butylparaben on liver weight of $\mathrm{C} 3 \mathrm{H}$ mice

\begin{tabular}{|c|c|c|c|}
\hline Compound & Dose $(\mathrm{mg} / \mathrm{kg} \mathrm{bw})$ & Route & Liver weight (in mg) \\
\hline Oil & $20 \mu \mathrm{l}($ per animal $)$ & Sc & $1.342 \pm 0.0106^{*}$ \\
\hline $\mathrm{E}_{2}$ & $500 \mathrm{ng}$ & $\mathrm{Sc}$ & $1.781 \pm 0.160^{*}$ \\
\hline BuPben & 500 & $\mathrm{Sc}$ & $1.470 \pm 0.0170^{*}$ \\
\hline BuPben & 1000 & Sc & $1.547 \pm 0.0121^{*}$ \\
\hline
\end{tabular}

* indicates significance at $\mathrm{p}<0.01$ compared to olive oil (vehicle control group).

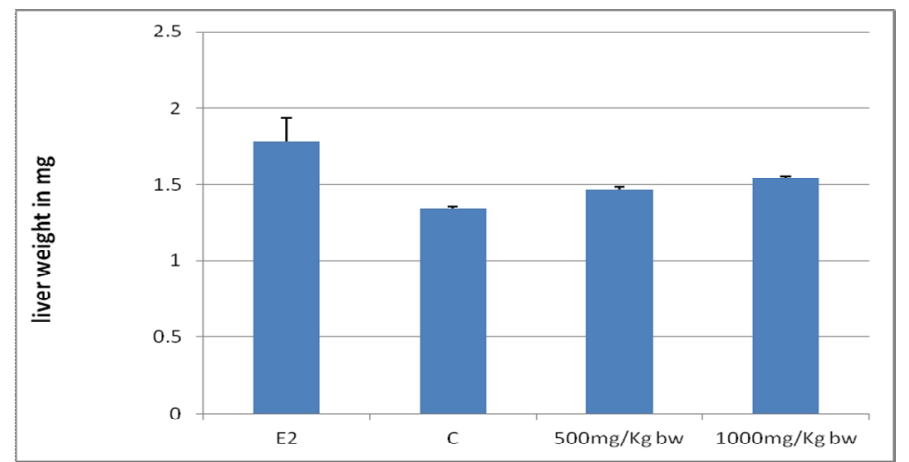

Figure 1: Butylparaben is found to shows an increase in liver weight of $\mathrm{C} 3 \mathrm{H}$ mice even though potency lowers than estradiol (p<0.01\%)

\section{RESULTS}

The treatment of ovariectomised adult $\mathrm{C} 3 \mathrm{H}$ mice with estradiol and two different dose level of butylparaben for seven consecutive doses showed change in liver weight. The estradiol treated group showed significant increase in liver weight of $1.781 \pm 0.160 \mathrm{mg}(\mathrm{p}<0.01)$ compared to vehicle control group (olive oil) of $1.342 \pm 0.0106 \mathrm{mg}$. $500 \mathrm{mg} / \mathrm{kg}$ body weight/day and $1000 \mathrm{mg} / \mathrm{kg}$ body weight/day showed a significant increase in liver weight $(\mathrm{p}<0.01)$ as compared to vehicle control (olive oil) of $1.470 \pm 0.0170 \mathrm{mg}$ and $1.547 \pm 0.021 \mathrm{mg}$. (Table 1 and Figure 1)

\section{DISCUSSION}

Significant Increase in liver weight of $\mathrm{C} 3 \mathrm{H}$ albino mice at doses $500 \mathrm{mg} / \mathrm{kg}$ body weight/day and $1000 \mathrm{mg} / \mathrm{kg}$ body weight/day compared to control explains the effect of butylparaben on liver. Many people are unaware of health and environmental concern has emerged among scientists around the world because of the wide use of butylparaben in the environment. Understanding these topics is essential for educating the public and medical professionals about potential risks associated with exposure of endocrine disruptors.

Even though this preservative to which human is widely exposed possess low estrogenic activity, the broad used of it by human is a matter of concern. Thus, the safety of the wide use of chemical should be reassessed ${ }^{1,8}$.

\section{REFERENCES}

1. Kummerer K. Pharmaceuticals in the Environment: Sources, Fate, Effects and Risks. $3^{\text {rd }}$ ed. Berlin: Springer publisher: 2001.

2. Odum J, Ashby J, Sumpter JP. Some alkyl hydroxy benzoate preservatives (parabens) are estrogenic. Toxicology and Applied Pharmacology.1998;153: 12-19. $\quad$ http://dx.doi.org/10.1006 /taap.1998.8544 PMid:9875295

3. Crofton KM. Short-term in vivo exposure to the water contaminant triclosan: Evidence for disruption of thyroxine. Environmental Toxicology and Pharmacology. 2007;24: 194-197. http://dx.doi.org/ 10.1016/j.etap.2007.04.008 PMid:21783810

4. Fent K, AA Weston, D Caminada. Ecotoxicology of human pharmaceuticals. Aquat. Toxicol. 2006;76:122-159. http:// dx.doi.org/10.1016/j.aquatox.2005.09.009 PMid:16257063

5. PD Darbre, JR Byford, LE Shaw, RA Horton, GS Pope, MJ Sauer Oestrogenic activity of isobutylparaben in vitro and in vivo. Journal of Applied Toxicology. 2002;22: 219-226. http://dx.doi.org/ 10.1002/jat.860 PMid: 12210538

6. A Hossani, JJ Larsen, JC Larsen. Lack of oestrogenic effects of food preservatives (parabens) in uterotrophic assays. Food and Chemical Toxicology. 2000;38: 319-323. http://dx.doi.org/ 10.1016/S0278-6915(99)00160-X

7. Oishi S. Effects of butyl paraben on the male reproductive system in mice. Archives of Toxicology. 2002;76: 423-429. http:// dx.doi.org/10.1007/s00204-002-0360-8 PMid:12111007

8. Harvey and Everett, PW Harvey and DJ Everett. Significance of the detection of esters of p-hydroxybenzoic acid (parabens) in human breast tumours, J. Appl. Toxicol. 2004;24:1-4 http://dx.doi.org/ 10.1002/jat.957 PMid: 14745840

9. Miller D, Wheals BB, Beresford N, Sumpter JP. Estrogenic activity of phenolic additives determined by an in vitro yeast bioassay. Environmental Health Perspectives. 2001;109:133-138. PMid:11266322 PMCid:1240632

Cite this article as:

Pallabi Goswami, J.C Kalita. Effect of high dose of Butylparaben on liver weight of ovariectomised $\mathrm{C} 3 \mathrm{H}$ albino mice. Int. J. Res. Ayur. Pharm. 2013; 4(1):90-91 